AperTO - Archivio Istituzionale Open Access dell'Università di Torino

\title{
Education Capability: A Focus on Gender and Science
}

\section{This is the author's manuscript}

Original Citation:

Availability:

This version is available http://hdl.handle.net/2318/1527049

since 2017-12-05T10:52:45Z

Published version:

DOI:10.1007/s11205-015-1057-8

Terms of use:

Open Access

Anyone can freely access the full text of works made available as "Open Access". Works made available under a Creative Commons license can be used according to the terms and conditions of said license. Use of all other works requires consent of the right holder (author or publisher) if not exempted from copyright protection by the applicable law. 


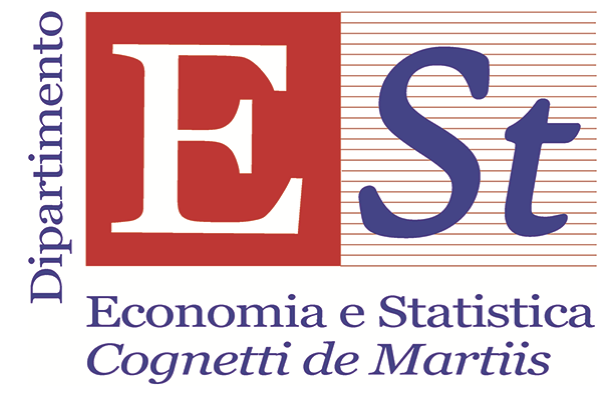

\title{
Working Paper Series
}

\section{EDUCATION CAPABILITY: A FOCUS ON GENDER AND SCIENCE}

\author{
TINDARA ADDABBO, MARIA LAURA DI TOMMASO \\ and ANNA MACCAGNAN
}





\title{
Education capability: a focus on gender and science
}

\author{
Tindara Addabbo \\ Department of Economics “Marco Biagi”, University of Modena and Reggio Emilia \\ Centre for the Analysis of Public Policies - CAPP \\ tindara.addabbo@unimore.it \\ Maria Laura Di Tommaso \\ Department of Economics and Statistics "Cognetti de Martiis", University of Torino \\ Collegio Carlo Alberto \\ Centre for Household Income Labour and Demographic Economics - CHILD \\ marialaura.ditommaso@unito.it
}

\author{
Anna Maccagnan \\ Department of Economics “Cognetti de Martiis”, University of Torino \\ anna.maccagnan@unito.it
}

\begin{abstract}
The focus of the paper is on the measurement of science education capability with a gender perspective.

Measuring science education capability implies going beyond the measurement of children test scores. In the capability approach, we aim at the real opportunities that children can develop later in life and therefore it is important to include some measures of non-cognitive skills. We utilize, therefore, different indicators in addition to test scores in science: enjoyment in science, interest in science, general and personal values of science, self-confidence in performing science related tasks, awareness and perception of environmental issues, and responsibility for sustainable development.

We utilize the 2006 PISA survey for Italian 15 year old children because it contains a particular focus on science and we estimate a Structural Equation Model to take into account that capabilities are latent constructs of which we only observe some indicators. We also investigate the determinants of children's science education capability in Italy taking into account household, individual and school factors.

Results confirm that boys outperform girls in science education capability. Our theoretical construct for the science education capability confirms that all the indicators are relevant to measure this capability. School activities to promote sciences improve girls' capability and interactive methods of teaching improve both girls and boys capability. The household educational resources and the household educational possession are also positively correlated with girls' and boys' science education capability.
\end{abstract}

Keywords: Capabilities; Education; Science; Structural Equation Modelling; Children; Gender JEL codes: I20; C35; B54

\section{Acknowledgements}

Previous versions of this paper have been presented at the "Human Capital: Definition and Measurement" Conference, Rome, 17 November 2010; at the "Children's Capabilities and Human Development: Researching Inside and Outside of Schools" Conference, Cambridge, 11-12 April 2011; at the "Measuring Human Development and Capabilities in High-Income Countries" Conference, Rome, 14-15 April 2014; at the HDCA 2014 Conference, Athens, 2-5 September 2014. The authors would like to thank the participants to the conferences for their stimulating comments. 


\section{Introduction}

The education capability is a crucial dimension of child well-being. Many scholars within the capability approach have underlined its importance. It is an essential capability in its own, in expanding agency, and as a basis for other capabilities (Hart 2014; Terzi 2007).

Nussbaum (2003) provides a broad definition of this capability: “Capability of Senses Imagination and Thought: Being able to use the senses, to imagine, think, and reason and do these things in a "truly human" way informed and cultivated by an adequate education, including by no means limited to, literacy and basic material skills” (Nussbaum 2003, 41).

Biggeri and Libanora (2011) ask directly to children to define a list of capabilities and to give a value to the education capability: $92 \%$ of the children consider education a "very important" capability. Other researchers underline the importance of the capability approach to define a broader concept of education outcomes (Kelly 2012; Walker 2005). In particular, schooling and tests' outcomes can be seen as a mean to enhance children opportunities in the capability approach. Other authors in the capabilities literature propose definitions of the education capability (Terzi 2007; Nussbaum 1997; Hart 2014) and analyse the role of educational institutions in fostering human well-being (Hart 2014; Biggeri 2014; Vaughan and Walker 2012; Walker and Unterhalter 2007).

Science and technology are considered a basic capability for educational functionings by Terzi $(2007,37)$ together with literacy, numeracy, sociality and participation, learning dispositions, physical activities and practical reason.

In this paper, we focus on the science education capability for Italian children in a gender perspective. Following the capability literature on education and the educational literature on noncognitive skills (Sikora and Pokropek 2012; Gutman and Schoon 2013), we believe that the use of test scores is limited. In the capability approach, we aim at the real opportunities that children can develop later in life and therefore it is important to include some measures of non-cognitive skills. We utilize, therefore, different indicators in addition to test scores in science: enjoyment in science, 
interest in science, general and personal values of science, self-efficacy (confidence in performing science related tasks), awareness and perception of environmental issues, and responsibility for sustainable development.

We apply the simplest Structural Equation Model, a Multiple Indicator Multiple Cause model (MIMIC), to OECD PISA 2006 micro-data for Italy. The MIMIC model implies that the science capability is a latent construct of which it is possible to observe only some functionings (the indicators listed above). The estimates allow the identification of individual, family and institutional factors that are correlated with the science education capability.

The Italian PISA data provide a relevant example of a country with low achievements on science test scores and high level of gender inequality in the society. OECD (2007) shows that the Italian average test score in science is equal to 475 (477 for males and 474 for females), against an OECD average equal to 500. Further, according to EIGE (2013), the gender equality index in Italy is 40.9 against an EU-28 average by 54 .

The paper is organized as follows: Section 2 presents the existing literature focusing on the gender gap in science, and on the family and institutional conversion factors referred to this capability. Data and descriptive statistics are provided in Section 3. The MIMIC model is described in Section 4 and the results of the estimated model are shown in Section 5. The last Section draws conclusions.

\section{Gender differences in science}

Gender differences in science test scores (and more in general in the so-called STEM: Science Technology Engineering and Math disciplines) are widespread in most countries in the world. These differences justify the gender perspective that we take in this analysis. Among others, de San Roman and de La Rica Goiricelaya (2012) find math gender gaps among OECD countries. They find that the average gap in maths is equal to -8.64 in PISA 2009; this gap is lower for the lower percentiles (-7.01 for the 5th percentile and -20.33 for the 95 th percentile). Moreover, they find that 
differences in cultural and social norms across countries and across regions within the same country are crucial determinants in understanding gender differences in PISA 2009 test scores: girls perform relatively better in both math and reading in societies with high gender equality. In addition, they find substantial evidence for the intergenerational transmission of gender role attitudes, especially from mothers to daughters, as the performance of girls - not that of boys - is better in families where the mother works outside home.

The literature shows that the gender gap in sciences does not emerge until high school. This result suggests that gender differences are due to socialization and to the educational process rather than connected to biological factors (Good, Woodzicka, and Wingfield 2010; Bleeker and Jacobs 2004; Brownlow and Durham 1997). Sikora and Pokropek (2012) using data from PISA 2006 surveys for 50 countries analyse gender differences in science and they find that the male-female gap in science self-concept (similar to our self-efficacy in Table 1) is larger in advanced industrial countries.

\section{Family involvement}

Parents' perception of child ability, parental involvement in homework, sex-stereotypes in parent's evaluation of children abilities affect achievements in science and children self-perception (amongst others: Jacobs 1991; Jacobs and Bleeker 2004; Jacobs and Eccles 1992; Bhanot and Jovanovic 2009; Twenge and Campbell 2001). Though gender gaps are decreasing over time, boys have better access to science-related resources than girls (Jacobs and Bleeker 2004).

Mothers' encouragement in science homework has a positive effect on girls' self-assessment of science ability, and a negative effect on boys' self-assessment. Mothers' science discussions have a similar effect on boys and girls beliefs about science (Bhanot and Jovanovic 2009). Moreover, the effect of parental involvement on children's out-of-school activities related to sciences and math are related to children's interest in science also later on in their life (Jacobs and Bleeker 2004). 


\section{Teaching Science}

Different approaches to math and physics increase gender inequality in achievements. Problemsolving, class-discussions and investigative work improve girls' perfomances (Boaler 2002; Zohar and Sela 2003). Boaler, Altendorff, and Kent (2011) analyse other factors affecting lower achievement in math and science, e.g. images shown in textbooks. Good, Woodzicka, and Wingfield (2010) show that, by using counter-stereotypic images with female scientists, girls' comprehension increases.

Moreover, children's overall self-perception of abilities is more affected by negative evaluation by others during teenagehood (Bhanot and Jovanovic 2009; Twenge and Campbell 2001).

\section{Data and descriptive statistics}

We utilize the 2006 survey of the Programme for International Student Assessment (PISA) conducted by the OECD. Our sample consists of 8582 boys and 8369 girls. PISA tests are collected on 15 year old children.

The 2006 PISA survey contains a particular focus on sciences, which is useful to extend the estimation of the education capability in science beyond test results. In particular, in addition to the test scores, we use data on interest in science, enjoyment in science, science self-efficacy (confidence in performing science related tasks), general and personal values of science, science activities, perception of environmental issues, responsibility for sustainable development and awareness of environmental issues as indicators of the cognitive capability in science. Each of these additional dimensions is a synthetic index of a set of items. Table 1 shows the lists of indicator for each index (see OECD 2009 for details). 
PISA provides normalized indicators: test scores' mean is equal to 500 and their standard deviation equal to 100 at the whole OECD level, while table 1 indices have zero mean and standard deviation equal to one. As our primary purpose is not to carry out an international comparison, but to compare Italian children by gender, in presenting these statistics, we re-normalize all these indices within our sample (i.e. the variables have been standardized to have zero mean and variance equal to one in the whole sample of boys and girls).

\section{TABLE 2 APPROXIMATELY HERE}

Table 2 shows boys' and girls' achievements in terms of the indicators of the latent science education capability. Last column of Table 2 shows the gender gap (male-female mean). As expected, we find a gender gap in the test scores in favour of boys equal to 0.13 standard deviations: boys' scores are 0.06 standard deviations above the overall mean and girls' scores are 0.06 below the overall mean. Gender gaps are higher for performing science activities $(+0.22)$ and for the general and personal value of science $(+0.22$ and +0.17 respectively). Boys' higher perception of personal value of science can also be correlated to different expectations in terms of future career. The percentage of male students in STEM's subjects in tertiary education is higher than that of girls (OECD 2012). In addition, STEM's related jobs are mainly males (OECD 2006).

Boys show also higher level of enjoyment in science $(+0.10)$. Boys are better off than girls also in self-efficacy in science $(+0.17)$, suggesting that boys are more confident (see Bhanot and Jovanovic 2009 for a survey). Boys show better achievements also in term of awareness of environmental problems $(+0.17)$, and, to a lesser extent, in terms of interest in scientific topics $(+0.02)$.

On the other hand, girls outperform boys in the perception of the gravity of environmental issues (by 0.17) and in the responsibility for carrying out activities towards sustainable development (by 0.08 ). 
Table 3 shows the description of the above-mentioned indicators and of exogenous individual, household and school variables.

\section{TABLE 3 APPROXIMATELY HERE}

At individual level, we consider gender and immigration status, also interacted.

At the household level, we consider the following variables: an index on the household's possession of cultural goods; an index of educational resources in the household; mother and father education; mother and father occupational status, also in terms of socio-economic occupational status (see Ganzeboom, De Graaf, and Treiman 1992).

School's variables include hours of science at school, a variable for participative teaching methods, a factor describing the development of activities for the promotion of science at school, the shortage of science teachers.

Table 4 shows descriptive statistics on the conversion factors described above. We have two types of variables: binary variables and continuous variables provided and scaled by PISA in a way similar to the one explained for the functioning indicators. Also in this table, we re-normalize continuous variables within our sample (i.e. the variables have been standardized to have zero mean and variance equal to one in the whole sample of boys and girls).

\section{TABLE 4 APPROXIMATELY HERE}

Table 4 shows that about 3.5 percent of children in our sample are immigrant. Mothers and fathers show a very similar educational level but they are very different in terms of occupation: one third of the mothers do not work in the labour market, this is against about 2 percent of the fathers; fathers are also better off in terms of socio-economic occupational status. As for the school factors, boys are more likely than girls to enjoy interactive teaching methods, science promotion activities, 
more hours of science at school (about 30 percent of boys have more than 4 hours weekly, against 26 percent of girls).

\section{The Multiple Indicator Multiple Causes model}

In presenting the MIMIC model - the simplest Structural Equation Model - we first introduce notation. We let

$Y^{O}=\left(Y_{1}^{O}, Y_{2}^{O}, Y_{3}^{O}, \ldots \ldots \ldots . . . Y_{m}^{O}\right)^{\prime}$

and $Y^{C}=\left(Y_{1}^{C}, Y_{2}^{C}, Y_{3}^{C}, \ldots \ldots \ldots . . . Y_{m}^{C}\right)^{\prime}$

denote, respectively $m \times 1$ vectors of ordinal and continuous indicators; $Y_{i}^{O} \in\{1, \ldots . ., v\} i=1, \ldots \ldots . . m$, where $\mathrm{v}$ represents the number of ordered categories and $Y^{C}$ represents the latent counterparts to $Y^{O}=\tau\left(Y^{C}\right)$ where $\tau($.$) denotes the one to one mapping between the vector of latent variables and$ the ordinal indicators. We will use $Y^{*}$ to denote an unobserved latent construct.

Our argument for choosing the MIMIC specification rests upon the belief that the parameters that are delivered by this approach represent the fundamental objects of interest. In single indicator models, each observed measure (test scores for example), here elements of the vector $Y^{O}$, is considered a single indicator of a matching unobserved construct, elements of $Y^{C}$, such that the moments of interest can be written as $E\left(Y^{O}\right)=\tau\left(Y^{C} \mid x\right)$.

In contrast multiple indicator models (Muthén 1979) link multiple observed measures (in this case the ten indicators of the science education capability) to a reduced dimension of underlying latent variables (science education capability). In this instance a single indicator model is not appropriate since the moments we wish to estimate are of the form $E\left(Y^{*} \mid Y^{O}\right)=\tau\left(Y^{C}, x\right)$. rather than $E\left(Y^{O}\right)=\tau\left(Y^{C} \mid x\right)$.

In our application, we are not interested in the impact of individual characteristics on each of the dimensions of science education capability. 
We have few priors on which to base hypothesis testing with respect to individual dimensions (for instance there is no reason to expect that mother education will affect test scores or interest in science).

We construct a system of equations which specify the relationship between an unobservable latent variable $Y^{*}$ (science education capability), a set of observable endogenous ordinal indicators $Y^{O}$ (the functionings), and a set of observable exogenous variables $X$ (causes e.g. individual, school and household variables).

The structure of the model is as follows:

$\mathrm{Y}=\Lambda^{\mathrm{Y}} \mathrm{Y}^{*}+\varepsilon, \mathrm{j}=1, \ldots \ldots . ., \mathrm{m}$

where

$Y=\left(Y_{1}, Y_{2}, Y_{3}, \ldots \ldots \ldots . . Y_{m}\right)^{\prime}$ is a $m \times 1$ vector with each element representing an independent indicator of science education capability, denoted $Y^{*} . \Lambda^{Y}=\left\{\Lambda_{1}^{Y}, \Lambda^{Y}{ }_{2}, \Lambda^{Y}{ }_{3} \ldots . . \Lambda^{Y}{ }_{j}\right\}^{\prime}$ denotes a $m \times 1$ parameter vector of factor loadings, with each element representing the expected change in the respective indicators following a one unit change in the latent variable. $\varepsilon$ is a $m \times 1$ vector of measurement errors, with $\Theta_{\varepsilon}$ denote the covariance matrix.

In addition, we posit that science education capability is linearly determined by a vector of observable exogenous variables $x=\left(x_{1}, x_{2}, \ldots . . x_{s},\right)^{\prime}$ and a stochastic error $\varsigma$ giving, $Y^{*}=x^{\prime} \gamma+\varsigma$

where $\gamma$ is a $s \times 1$ vector of parameters.

Examining (1) and (2) we may think of our model as comprised of two parts: (2) is the structural (or state) equation and (1) is the measurement equation reflecting that the observed measurements are imperfect indicators. The structural equation specifies the casual relationship between the observed exogenous causes and science education capability. Since $Y^{*}$ is unobserved, it 
is not possible to recover direct estimates of the structural parameters $\gamma$. Combining (1) and (2) the reduced form representation is written as

$y=\pi x+v$

where $\pi=\Lambda^{Y} \gamma^{\prime}$ is the $m \times s$ reduced form coefficient matrix and $v=\Lambda^{Y} \varsigma+\varepsilon$ is the reduced form disturbance.

SEM has been widely used in the capability literature (see, among others, the work by Kuklys 2005; Di Tommaso 2007; Krishnakumar 2007; Anand, Krishnakumar, and Tran 2011).

In this paper we define the science capability as a latent variable that is expressed through the set of observable functionings of Table 2 above: test scores, interest in science, enjoyment in science, science self-efficacy, general and personal values of science, science activities, perception of environmental issues, responsibility for sustainable development and awareness of environmental issues.

The development of this capability depends on the set of conversion factors listed in Table 3 and 4. Individual factors: child's gender and migration status. Household factors: cultural possession at home, educational resources in the household, mother's and father's education and employment status; school factors: hours of science at school, interactive teaching methods, activities for the promotion of science, and a shortage of qualified science teachers.

The model can be schematized as in Figure 1.

\section{FIGURE 1 APPROXIMATELY HERE}

\section{Results of the estimation of the MIMIC model}

In this Section, we report the results of the estimation of the structural equation model presented above. In the estimation results, we show both the standardized and unstandardized solutions. Both are meaningful. The unstandardized solution is achieved by setting a lambda parameter equal to 1 and it also reports the standard errors and significance level of the variable coefficient. The 
disadvantage of unstandardized solutions is that they are not easily interpretable, as they refer to changes in variables that have no clear and heterogeneous measurement unit. The standardized solution overcomes this problem. Standardization is achieved by setting the variance of the latent variable equal to 1 , therefore standardized coefficients can be read as the standard deviation change in the dependent variable, that follows one standard deviation change in the independent variable.

Table 5 reports the results of the measurement equation.

\section{TABLE 5 APPROXIMATELY HERE}

All the functionings that have been considered are relevant and positively related to the development of the science capability. This is true both for the overall model (first column) and for the model estimated separately by gender (second and third column). Moreover, with very little differences by gender, the standardized coefficients are the highest for enjoyment of science, personal value of science and interest in science, suggesting that these variables are the most sensitive to changes in the science capability. Test scores, on the contrary, show the second lowest standardized coefficient. This result supports our choice of introducing other indicators of the latent science education capability.

\section{TABLE 6 APPROXIMATELY HERE}

Looking at the structural model, the results (Table 6) show that the science capability is more developed for boys: looking at column one the coefficient for the female dummy is negative and statistically significant. This result leads us to estimate the same model on the two subsamples of boys and girls in order to analyse the differences in the effect of the conversion factors (second and third column). 
Looking at the standardized coefficients, the most relevant variables are household's cultural possession, educational resources, number of hours dedicated to science, and interactive methods of teaching.

Cultural possession at home and educational resources have a positive and significant effect on the development of science capability for both girls and boys, and they are both higher for boys. This is consistent with previous literature (see for instance Peraita and Sánchez 1998 and, with regards to youngest children development, Yeung, Linver, and Brooks-Gunn 2002, amongst others).

The number of hours dedicated to science and interactive methods of teaching are positively correlated with both girls' and boys' science capability. Promotion activities in science have a lower positive parameter and it is significant for girls only. Being in a school characterized by a science teachers shortage negatively affects only boys' science capability. This can be determined by a higher need of teacher's supervision shown by boys in their education process.

Being a migrant does not significantly affect science capability. This is not consistent with other results where racial disparities continue to increase throughout high school (Bacharach, Baumeister, and Furr 2003).

Parents' level of education plays a higher positive effect on girls'. In particular, the parameters for mothers' educational levels are only statistically significant for girls while fathers' education affects both girls and boys but with a higher effect on girls. These results are consistent with Kleinjans' (2010) analysis on the effect of parental education and income on the educational expectations of children at age 19 in Denmark. For the USA, Bhanot and Jovanovic (2009) find a positive effect of mothers' encouragement only on girls' self-assessments of science ability at the end of the year.

Mothers' employment status below the mean or jobless status negatively affects only boys' science capability whereas fathers' employment status below average negatively affects only girls' achievements in science. This, given the higher father's household income share can be related to a 
positive correlation between household's income and girls' achievement in science. Evidence on the positive impact of household's income on children's achievement in science have been found amongst others by Beaumont-Walters and Soyibo (2001).

Differently from what has been found in other contexts, for instance in UK by Boaler, Altendorff, and Kent (2011), interactive methods of teaching do not play a positive role only for girls: in our estimates, they affect both boys' and girls' achievement in science. This result, though specific to the science education capability, is in line with the literature on the positive effect of participatory methods to the development of education capabilities (Hart 2014; Biggeri 2014).

On the other hand, promotion of science activities positively affects only girls' achievements in science. To reduce the gender gap in science, these types of activities should be promoted.

Finally, the fit of the model is satisfying as shown by the Standardized Root Mean Square Residual (SRMR) below 0.08 .

\section{Conclusions}

This paper analyses gender differences in science education capability in Italy, a country characterized by a lower than OECD-average achievement of test scores in science (according to PISA 2006 survey) and by a gender gap at the disadvantage of girls. We utilise a structural equation model, a technique increasingly used in the measurement of capabilities. We measure the education capability as a latent variables of which we observe ten indicators. All the chosen indicators significantly contribute to the latent science capability, showing that it is relevant not to limit the analysis to test scores.

The structural part of the estimated model reveals different impact of institutional and family variables by gender. In particular, we find that activities to promote sciences have a greater effect on girls' capability. Therefore, policies oriented to improve these activities could reduce the gender gap. Among the policies that can reduce the gender disparities in STEM subjects, OECD 
(2012) suggests addressing gender stereotypes in textbooks and developing teaching strategies and learning materials to encourage girls' involvement. Interactive methods of schooling have a positive effect both on girls and on boys and, together with cultural and educational resources at household's level, have the highest impact on boys and girls science capability. Given Italian children low achievements in science (respect to OECD average), these results call for higher investment in education and cultural family possessions and for the adoption of more interactive and less traditional teaching methods. 


\section{Table 1 - Items measuring each index}

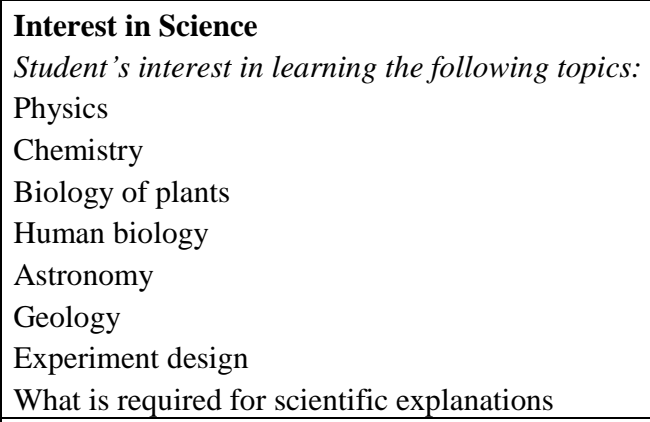

\section{Enjoyment in sciences}

Student's replies on the degree of agreement to the following statements:

Generally I have fun in learning science

I like reading about science

I'm happy doing science problems

I enjoy acquiring new knowledge in science

I am interested in learning about science

\section{Self-efficacy}

Student's replies on the degree of agreement to the following statements:

Learning advanced scientific topics is easy for me

I can usually give good answers in scientific tests

I learn science topics quickly

Science topics are easy for me

I can understand scientific topics very well

I can easily understand new ideas in science

\section{General value of science}

Student's replies on the degree of agreement to the following statements:

Advances in broad science and technology usually improve people's living conditions

Broad science is important for helping us to understand the natural word

Broad science is valuable to society

Advances in broad science and technology usually bring social benefits

\section{Personal value of science}

Student's replies on the perception of the value attached to science on personal grounds in terms of:

Helping in relating to other people

Use when adult

Understanding things around oneself

High relevance

\section{Science activities}

Frequency of the following activities:

Watch TV programmes about broad science

Borrow or buy books on broad science topics

Visit web sites about broad science topics

Listen to radio programmes about advances in broad science

Read broad science magazines or science articles in newspapers

\section{Perception of environmental issues}

Student's perception about the serious concern for him/her or others of the following problems:

Air pollution

Energy shortages

Extinction of plants and animals

Clearing of forests for other land use

Water shortages

Nuclear waste

\section{Responsibility for sustainable development}

Student's agreement on the following statements:

It is important to carry out regular checks on the emissions from car as a condition of their use

It disturbs me when energy is wasted through the unnecessary use of electrical appliances

I am in favour of having laws that regulate factory emission even if this would increase the price of products 
To reduce waste the use of plastic packaging should be kept to a minimum

Industries should be required to prove that they safely dispose of dangerous waste materials

I am in favour of having laws that protect the habitats of endangered species

Electricity should be produced from renewable sources as much as possible, even if this increases the cost

Awareness of environmental issues

Student's replies on the awareness to the following environmental issues:

Greenhouse gases

Genetically modified organisms

Acid rain

Nuclear waste

Consequences of clearing forests 
Table 2 - Descriptive statistics by gender on the scientific education capability indicators

\begin{tabular}{llllll}
\hline & M & & F & \multicolumn{2}{c}{ Gender Gap } \\
& Mean & SD & Mean & SD & M-F \\
\hline Test scores & 0.06 & 1.02 & -0.06 & 0.97 & 0.13 \\
Interest in science & 0.01 & 1.07 & -0.01 & 0.92 & 0.02 \\
Enjoyment of science & 0.05 & 1.03 & -0.05 & 0.97 & 0.10 \\
Science self-efficacy & 0.08 & 1.04 & -0.08 & 0.96 & 0.17 \\
General value of science & 0.11 & 1.06 & -0.11 & 0.93 & 0.22 \\
Personal value of science & 0.09 & 1.03 & -0.09 & 0.96 & 0.17 \\
Science activities & 0.11 & 1.01 & -0.11 & 0.97 & 0.22 \\
Perception of environmental issues & -0.08 & 1.00 & 0.09 & 0.99 & -0.17 \\
Responsibility for sustainable development & -0.04 & 1.04 & 0.04 & 0.96 & -0.08 \\
Awareness of environmental issues & 0.08 & 1.04 & -0.09 & 0.95 & 0.17 \\
\hline Obs. & 8582 & & 8369 & & \\
\hline
\end{tabular}

Source: Oecd PISA 2006 
Table 3 - Factors affecting the science education capability

\begin{tabular}{lll}
\hline Variable & Type & Description \\
\hline Cultural possessions & $\begin{array}{c}\text { Household factors } \\
\text { Continuous }\end{array}$ & $\begin{array}{l}\text { A index measuring possession of: classic literature, } \\
\text { books of poetry, works of art }\end{array}$ \\
Educational resources & Continuous & $\begin{array}{l}\text { A index measuring possession of: a desk to study at, a } \\
\text { quiet place to study, a computer the child can use for } \\
\text { school work, educational software, child own } \\
\text { calculator, books to help with school work, a } \\
\text { dictionary }\end{array}$
\end{tabular}

Mother and father educational level: Mother/Father degree

Mother/Father high school

Mother/Father less than high school degree

Mother and father occupational status:

Mother/Father not working

Mother/Father working \& sei below the mean

Mother/Father working \& sei above the mean
Binary

$=1$ if mother/father has a university degree; 0 otherwise

$=1$ if mother/father has a high school degree; 0 otherwise

$=1$ if mother/father with educational level lower than high school; 0 otherwise

Binary

$=1$ if mother/father not working; 0 otherwise

$=1$ if mother/father is working with a socio-economic occupational status (sei code) between 16 and 53;0 otherwise

$=1$ if mother/father is working with a socio-economic occupational status (sei code) between 54 and 90; 0 otherwise

\begin{tabular}{|c|c|c|}
\hline \multicolumn{3}{|c|}{ Personal factor } \\
\hline Female & Binary & $=1$ if female; 0 if male \\
\hline Immigrant & Binary & $=1$ if immigrant; 0 otherwise \\
\hline Female*Immigrant & Binary & $=1$ if female \& immigrant; 0 otherwise \\
\hline \multicolumn{3}{|c|}{ School factor } \\
\hline Weekly hours of science at school: & Binary & \\
\hline 0 hours & & $=1$ if 0 hours; 0 otherwise \\
\hline More than 0 , less than 2 & & $=1$ if more than 0 less than 2 hours; 0 otherwise \\
\hline More than 2, less than 4 & & $=1$ if more than 2 less than 4 hours; 0 otherwise \\
\hline More than 4 , less than 6 & & $=1$ if more than 4 less than 6 hours; 0 otherwise \\
\hline More than 6 & & $=1$ if more than 6 hours; 0 otherwise \\
\hline Interactive teaching methods & Continuous & $\begin{array}{l}\text { A index summing up the frequency of: interactive } \\
\text { teaching in science lessons, hands-on-activities, } \\
\text { student investigations, lessons with a focus on } \\
\text { applications }\end{array}$ \\
\hline Promotion of science (principal) & Continuous & $\begin{array}{l}\text { A index measuring school involvement in activities } \\
\text { promoting students' engagement with science: science } \\
\text { clubs, science fairs, science competitions, } \\
\text { extracurricular science projects, excursions and field } \\
\text { trips }\end{array}$ \\
\hline Shortage of science teachers (principal) & Binary & $\begin{array}{l}=1 \text { if the school is lacking "to some extent" or "a lot" } \\
\text { in qualified science teachers; } 0 \text { if "not at all" or "very } \\
\text { little" }\end{array}$ \\
\hline
\end{tabular}

Note: if "principal" is specified, the school's principal reports the information 
Table 4 - Descriptive statistics by gender on the conversion factors

\begin{tabular}{|c|c|c|c|c|}
\hline \multirow{2}{*}{ Continuous variables } & \multicolumn{2}{|l|}{$\mathrm{M}$} & \multicolumn{2}{|l|}{$\mathrm{F}$} \\
\hline & & & & \\
\hline & Mean & SD & Mean & SD \\
\hline Cultural possessions & -0.08 & 1.03 & 0.08 & 0.96 \\
\hline Educational resources & 0.03 & 0.99 & -0.03 & 1.00 \\
\hline Interactive teaching methods & 0.16 & 1.03 & -0.16 & 0.94 \\
\hline Promotion of science & 0.03 & 0.97 & -0.03 & 1.03 \\
\hline \multicolumn{5}{|l|}{ Binary variables } \\
\hline & \multicolumn{2}{|c|}{ Percentage } & \multicolumn{2}{|c|}{ Percentage } \\
\hline \multicolumn{5}{|l|}{ Mother educational level: } \\
\hline Mother degree & \multicolumn{2}{|l|}{$21.0 \%$} & \multicolumn{2}{|l|}{$14.5 \%$} \\
\hline Mother high school & \multicolumn{2}{|l|}{$33.6 \%$} & \multicolumn{2}{|l|}{$33.4 \%$} \\
\hline Mother less than high school & \multicolumn{2}{|l|}{$45.4 \%$} & \multicolumn{2}{|l|}{$52.1 \%$} \\
\hline \multicolumn{5}{|l|}{ Father educational level: } \\
\hline Father degree & \multicolumn{2}{|l|}{$20.4 \%$} & \multicolumn{2}{|l|}{$15.6 \%$} \\
\hline Father high school & \multicolumn{2}{|l|}{$35.1 \%$} & \multicolumn{2}{|l|}{$35.5 \%$} \\
\hline Father less than high school & \multicolumn{2}{|l|}{$44.5 \%$} & \multicolumn{2}{|l|}{$48.9 \%$} \\
\hline \multicolumn{5}{|l|}{ Mother occupational status: } \\
\hline Mother not working & \multicolumn{2}{|l|}{$33.4 \%$} & \multicolumn{2}{|l|}{$32.9 \%$} \\
\hline Mother working \& sei below the mean & \multicolumn{2}{|l|}{$53.4 \%$} & \multicolumn{2}{|l|}{$55.7 \%$} \\
\hline Mother working \& sei above the mean & \multicolumn{2}{|l|}{$13.2 \%$} & \multicolumn{2}{|l|}{$11.4 \%$} \\
\hline \multicolumn{5}{|l|}{ Father occupational status: } \\
\hline Father not working & \multicolumn{2}{|l|}{$1.7 \%$} & \multicolumn{2}{|l|}{$2.0 \%$} \\
\hline Father working \& sei below the mean & $79.1 \%$ & & $81.2 \%$ & \\
\hline Father working \& sei above the mean & $19.2 \%$ & & $16.9 \%$ & \\
\hline Immigrant & $3.4 \%$ & & $3.5 \%$ & \\
\hline Hours of science & & & & \\
\hline 0 hours & $6.6 \%$ & & $4.4 \%$ & \\
\hline More than 0 less than 2 & $25.0 \%$ & & $21.3 \%$ & \\
\hline More than 2 less than 4 & $38.5 \%$ & & $48.3 \%$ & \\
\hline More than 4 less than 6 & $15.7 \%$ & & $15.6 \%$ & \\
\hline More than 6 & $14.2 \%$ & & $10.4 \%$ & \\
\hline Shortage of science teachers & $12.6 \%$ & & $12.8 \%$ & \\
\hline Obs. & 8582 & & 8369 & \\
\hline
\end{tabular}

Source: Oecd PISA 2006 
Figure 1 - Path diagram of the MIMIC model

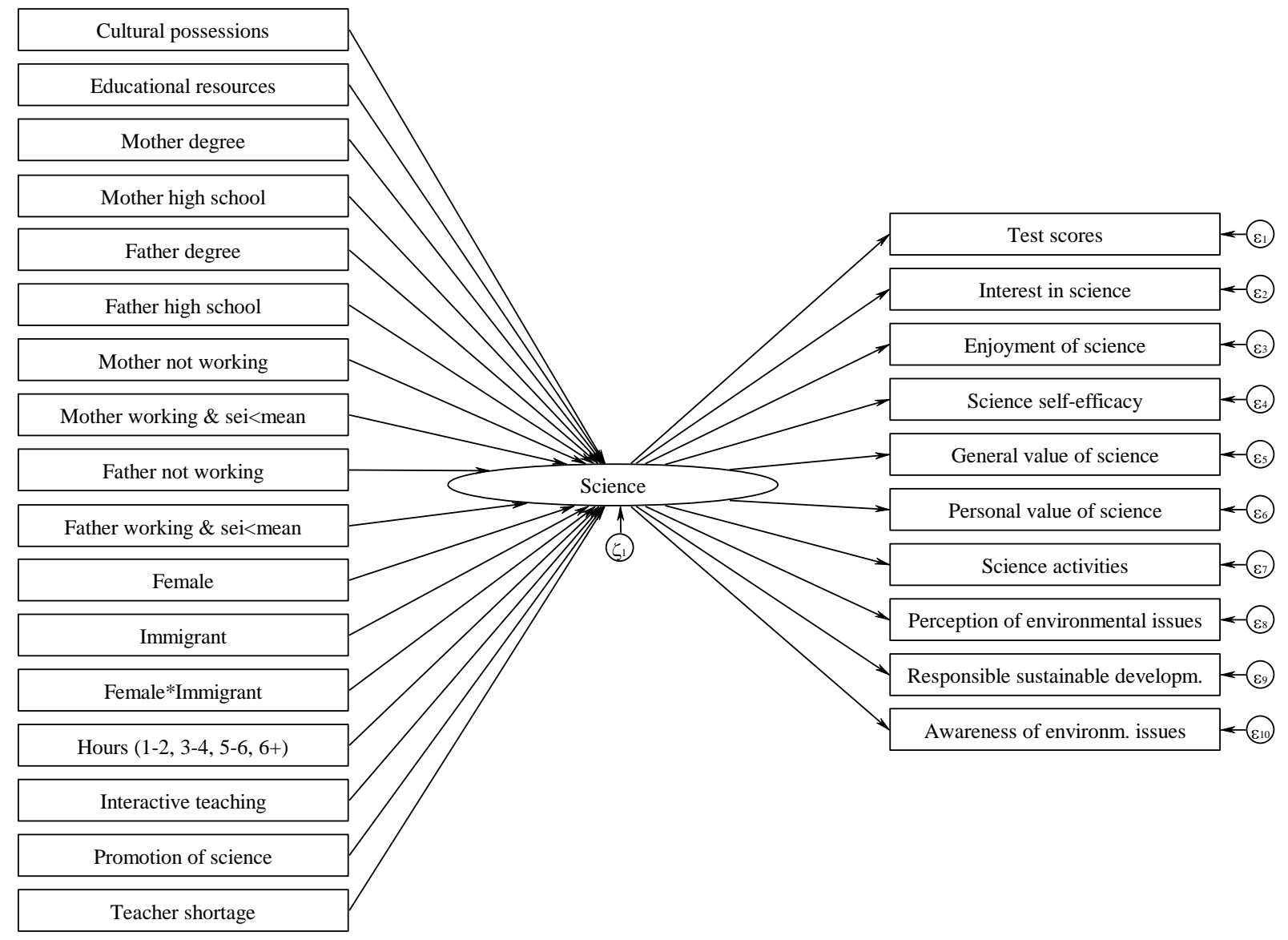


Table 5 - Results of the MIMIC Model: Measurement equation results

\begin{tabular}{|c|c|c|c|c|c|c|}
\hline & $\mathrm{M}+\mathrm{F}$ & & M & & $\mathrm{F}$ & \\
\hline & Unstd. & Std. & Unstd. & Std. & Unstd. & Std. \\
\hline Test scores & 1.000 & 0.350 & 1.000 & 0.352 & 1.000 & 0.335 \\
\hline & - & & - & & - & \\
\hline Interest in science & $0.019 * * *$ & 0.717 & $0.020 * * *$ & 0.721 & $0.019 * * *$ & 0.725 \\
\hline & $(0.001)$ & & $(0.001)$ & & $(0.001)$ & \\
\hline Enjoyment of science & $0.020 * * *$ & 0.738 & $0.020 * * *$ & 0.736 & $0.021 * * *$ & 0.742 \\
\hline & $(0.001)$ & & $(0.001)$ & & $(0.001)$ & \\
\hline Science self-efficacy & $0.013 * * *$ & 0.551 & $0.014 * * *$ & 0.579 & $0.013 * * *$ & 0.505 \\
\hline & $(0.001)$ & & $(0.001)$ & & $(0.001)$ & \\
\hline General value of science & $0.016 * * *$ & 0.566 & $0.017 * * *$ & 0.572 & $0.016 * * *$ & 0.543 \\
\hline & $(0.001)$ & & $(0.001)$ & & $(0.001)$ & \\
\hline Personal value of science & $0.019 * * *$ & 0.727 & $0.019 * * *$ & 0.730 & $0.020 * * *$ & 0.719 \\
\hline & $(0.001)$ & & $(0.001)$ & & $(0.001)$ & \\
\hline Science activities & $0.020 * * *$ & 0.680 & $0.019 * * *$ & 0.669 & $0.021 * * *$ & 0.685 \\
\hline & $(0.001)$ & & $(0.001)$ & & $(0.001)$ & \\
\hline Perception of environmental issues & $0.005 * * *$ & 0.160 & $0.006 * * *$ & 0.199 & $0.004 * * *$ & 0.142 \\
\hline & $(0.000)$ & & $(0.001)$ & & $(0.001)$ & \\
\hline Responsibility for sustainable development & $0.011 * * *$ & 0.411 & $0.012 * * *$ & 0.431 & $0.011 * * *$ & 0.405 \\
\hline & $(0.001)$ & & $(0.001)$ & & $(0.001)$ & \\
\hline Awareness of environmental issues & $0.015 * * *$ & 0.492 & $0.015 * * *$ & 0.494 & $0.014 * * *$ & 0.477 \\
\hline & $(0.001)$ & & $(0.001)$ & & $(0.001)$ & \\
\hline Obs. & 16951 & & 8582 & & 8369 & \\
\hline
\end{tabular}

Source: Oecd PISA 2006

Robust standard errors in parentheses

$* * * \mathrm{p}<0.01 ; * * \mathrm{p}<0.05 ; * \mathrm{p}<0.10$ 
Table 6 - Results of the MIMIC Model: Structural equation results

\begin{tabular}{|c|c|c|c|c|c|c|}
\hline & \multicolumn{2}{|l|}{$\mathrm{M}+\mathrm{F}$} & \multicolumn{2}{|l|}{ M } & \multicolumn{2}{|l|}{$\mathrm{F}$} \\
\hline & Unstd. & Std. & Unstd. & Std. & Unstd. & Std. \\
\hline \multicolumn{7}{|l|}{ HOUSEHOLD VARIABLES } \\
\hline Cultural possession & $\begin{array}{l}7.594 * * * \\
(0.558)\end{array}$ & 0.196 & $\begin{array}{l}8.147 * * * \\
(0.801)\end{array}$ & 0.210 & $\begin{array}{l}6.701 * * * \\
(0.743)\end{array}$ & 0.178 \\
\hline Educational resources & $\begin{array}{l}4.493 * * * \\
(0.427)\end{array}$ & 0.139 & $\begin{array}{l}5.427 * * * \\
(0.632)\end{array}$ & 0.162 & $\begin{array}{l}3.364 * * * \\
(0.554)\end{array}$ & 0.113 \\
\hline \multicolumn{7}{|c|}{ Mother educational level - ref. group: lower than high school degree } \\
\hline Mother degree & $\begin{array}{l}1.644 \\
(1.219)\end{array}$ & 0.021 & $\begin{array}{l}-0.463 \\
(1.684)\end{array}$ & -0.006 & $\begin{array}{l}4.583 * * * \\
(1.717)\end{array}$ & 0.057 \\
\hline Mother high school & $\begin{array}{l}1.388^{*} \\
(0.826)\end{array}$ & 0.021 & $\begin{array}{l}0.874 \\
(1.226)\end{array}$ & 0.013 & $\begin{array}{l}1.815^{*} \\
(1.083)\end{array}$ & 0.030 \\
\hline \multicolumn{7}{|c|}{ Father educational level - ref. group: lower than high school degree } \\
\hline Father degree & $\begin{array}{l}3.665 * * * \\
(1.252)\end{array}$ & 0.046 & $\begin{array}{l}2.831^{*} \\
(1.703)\end{array}$ & 0.036 & $\begin{array}{l}4.631 * * * \\
(1.767)\end{array}$ & 0.059 \\
\hline Father high school & $\begin{array}{l}3.171 * * * \\
(0.834)\end{array}$ & 0.049 & $\begin{array}{l}2.767 * * \\
(1.252)\end{array}$ & 0.042 & $\begin{array}{l}3.549 * * * \\
(1.064)\end{array}$ & 0.060 \\
\hline \multicolumn{7}{|c|}{ Mother occupational status - ref. group: working \& sei code above the mean } \\
\hline Mother not working & $\begin{array}{l}-3.120 * * \\
(1.337)\end{array}$ & -0.048 & $\begin{array}{l}-4.139 * * \\
(1.849)\end{array}$ & -0.062 & $\begin{array}{l}-0.996 \\
(1.838)\end{array}$ & -0.016 \\
\hline Mother working \& sei code below the mean & $\begin{array}{l}-3.329 * * * \\
(1.223)\end{array}$ & -0.054 & $\begin{array}{l}-4.121 * * \\
(1.691)\end{array}$ & -0.065 & $\begin{array}{l}-1.393 \\
(1.680)\end{array}$ & -0.024 \\
\hline \multicolumn{7}{|c|}{ Father occupational status - ref. group: working \& sei code above the mean } \\
\hline Father not working & $\begin{array}{l}-2.443 \\
(3.137)\end{array}$ & -0.011 & $\begin{array}{l}-3.074 \\
(3.913)\end{array}$ & -0.012 & $\begin{array}{l}-2.299 \\
(4.468)\end{array}$ & -0.011 \\
\hline Father working \& sei code below the mean & $\begin{array}{l}-2.303 * * \\
(1.011)\end{array}$ & -0.030 & $\begin{array}{l}-1.539 \\
(1.357)\end{array}$ & -0.020 & $\begin{array}{l}-3.005^{* *} \\
(1.449)\end{array}$ & -0.041 \\
\hline \multicolumn{7}{|l|}{ INDIVIDUAL VARIABLES } \\
\hline Female & $\begin{array}{l}-4.419 * * * \\
(0.759)\end{array}$ & -0.072 & & & & \\
\hline Immigrant & $\begin{array}{l}0.893 \\
(2.585)\end{array}$ & 0.005 & $\begin{array}{l}1.385 \\
(2.566)\end{array}$ & 0.008 & $\begin{array}{l}-1.983 \\
(2.144)\end{array}$ & -0.013 \\
\hline Female*immigrant & $\begin{array}{l}-1.860 \\
(3.318)\end{array}$ & -0.008 & & & & \\
\hline \multicolumn{7}{|l|}{ SCHOOL VARIABLES } \\
\hline \multicolumn{7}{|c|}{ Weekly hours of science at school - ref. group: 0 hours } \\
\hline Hours of science: more than 0 less than 2 & $\begin{array}{l}14.312 * * * \\
(1.850)\end{array}$ & 0.197 & $\begin{array}{l}12.896 * * * \\
(2.316)\end{array}$ & 0.177 & $\begin{array}{l}15.093 * * * \\
(2.877)\end{array}$ & 0.217 \\
\hline Hours of science: more than 2 less than 4 & $\begin{array}{l}22.705 * * * \\
(1.966)\end{array}$ & 0.367 & $\begin{array}{l}23.125^{* * * *} \\
(2.590)\end{array}$ & 0.356 & $\begin{array}{l}21.362 * * * \\
(2.957)\end{array}$ & 0.375 \\
\hline Hours of science: more than 4 less than 6 & $\begin{array}{l}28.300 * * * \\
(2.210)\end{array}$ & 0.336 & $\begin{array}{l}27.251 * * * \\
(2.863)\end{array}$ & 0.314 & $\begin{array}{l}28.255^{* * * *} \\
(3.381)\end{array}$ & 0.360 \\
\hline Hours of science: more than 6 & $\begin{array}{l}28.693 * * * \\
(2.290)\end{array}$ & 0.308 & $\begin{array}{l}27.369 * * * \\
(2.960)\end{array}$ & 0.302 & $\begin{array}{l}28.980 * * * \\
(3.501)\end{array}$ & 0.311 \\
\hline Interactive teaching methods & $\begin{array}{l}9.322 * * * \\
(0.507)\end{array}$ & 0.236 & $\begin{array}{l}9.516^{* * * *} \\
(0.728)\end{array}$ & 0.242 & $\begin{array}{l}8.958 * * * \\
(0.661)\end{array}$ & 0.230 \\
\hline Promotion of science & $\begin{array}{l}1.370 * * * \\
(0.422)\end{array}$ & 0.037 & $\begin{array}{l}0.633 \\
(0.638)\end{array}$ & 0.016 & $\begin{array}{l}1.946 * * * \\
(0.544)\end{array}$ & 0.058 \\
\hline Shortage of science teachers & $\begin{array}{l}-2.256^{* *} \\
(1.119)\end{array}$ & -0.025 & $\begin{array}{l}-3.841 * * \\
(1.726)\end{array}$ & -0.040 & $\begin{array}{l}-0.821 \\
(1.371)\end{array}$ & -0.010 \\
\hline SRMR & 0.037 & & 0.039 & & 0.041 & \\
\hline Obs. & 16951 & & 8582 & & 8369 & \\
\hline
\end{tabular}

Source: Oecd PISA 2006

Robust standard errors in parentheses

Notes: the reference category for parental education is parents with less than high school degree; for parental occupational status is working parents with sei code above the mean; for hours of science at school is zero hours. $* * * \mathrm{p}<0.01 ; * * \mathrm{p}<0.05 ; * \mathrm{p}<0.10$ 


\section{References}

Anand, Paul, Jaya Krishnakumar, and Ngoc Bich Tran. 2011. "Measuring Welfare: Latent Variable Models for Happiness and Capabilities in the Presence of Unobservable Heterogeneity." Journal of Public Economics 95 (3\&4): 205-215. doi: 10.1016/j.jpubeco.2010.11.007.

Bacharach, Verne R., Alfred A. Baumeister, and R. Michael Furr. 2003. "Racial and Gender Science Achievement Gaps in Secondary Education.” The Journal of Genetic Psychology: Research and Theory on Human Development 164 (1): 115-126. doi: $10.1080 / 00221320309597507$.

Beaumont-Walters, Yvonne, and Kola Soyibo. 2001. “An Analysis of High School Students' Performance on Five Integrated Science Process Skills." Research In Science \& Technological Education 19 ( 2): 133-145. doi: 10.1080/02635140120087687.

Bhanot, Ruchi T., and Jasna Jovanovic. 2009. “The Links between Parent Behaviors and Boys' and Girls’ Science Achievement Beliefs.” Applied Developmental Science 13 (1): 42-59. doi: $10.1080 / 10888690802606784$

Biggeri, Mario. 2014. "Education Policy for Agency and Participation." Chap. 2 in Agency and Participation in Childhood and Youth. International Applications of the Capability Approach in Schools and Beyond, edited by Caroline Hart, Mario Biggeri, and Bernhard Babic, 44-62. London: Bloomsbury Academic.

Biggeri, Mario, and Renato Libanora. 2011. "From Valuing to Evaluating: Tools and Procedures to Operationalize the Capability Approach.” Chap. 4 in Children and the Capability Approach, edited by Mario Biggeri, Jerome Ballet, and Flavio Comim, 76-106. Basingstoke: Palgrave Macmillan.

Bleeker, Martha M., and Janis E Jacobs. 2004. “Achievement in Math and Science: Do Mothers' Beliefs Matter 12 Years Later?” Journal of Educational Psychology 96 (1): 97-109. doi: 10.1037/0022-0663.96.1.97.

Boaler, Jo. 2002. "Paying the Price for 'Sugar and Spice': Shifting the Analytical Lens in Equity 
Research." Mathematical Thinking and Learning 4 (2\&3): 127-144. doi: 10.1207/S15327833MTL04023_3.

Boaler, Jo, Lori Altendorff, and Geoff Kent. 2011. "Mathematics and Science Inequalities in the United Kingdom: When Elitism, Sexism and Culture Collide." Oxford Review of Education 37 (4): 457-484. doi: 10.1080/03054985.2011.595551.

Brownlow, Sheila, and Staci Durham. 1997. "Sex Differences in the Use of Science and Technology in Children's Cartoons." Journal of Science Education and Technology 6 (2): 103-110. doi: 10.1023/A:1025661830339.

de San Román, Ainara González, and Sara de La Rica Goiricelaya. 2012. “Gender Gaps in PISA Test Scores: The Impact of Social Norms and the Mother's Transmission of Role Attitudes.” IZA Discussion Paper 6338.

Di Tommaso, Maria Laura. 2007. "Children Capabilities: A Structural Equation Model for India" Journal of Socio Economics 36: 436-450. doi: 10.1016/j.socec.2006.12.006.

EIGE (European Institute for Gender Equality). 2013. Gender Equality Index. Report. EIGE Publication. doi:10.2839/9948.

Ganzeboom, Harry B.G., Paul M. De Graaf, and Donald J. Treiman. 1992. "A Standard International Socio-Economic Index of Occupational Status.” Social Science Research 21: 1-56. doi: 1016/0049-089X(92)90017-B.

Good, Jessica J., Julie A. Woodzicka, and Lylan C. Wingfield. 2010. "The Effects of Gender Stereotypic and Counter-Stereotypic Textbook Images on Science Performance.” Journal of Social Psychology 150 (2): 132-147. doi: 10.1080/00224540903366552.

Gutman, Leslie Morrison, and Ingrid Schoon. 2013. Non-Cognitive Skills: Evidence and Intervention. Education Endowment Foundation.

Hart, Caroline. 2014. "The Capability Approach and Educational Research.” Chap.1 in Agency and Participation in Childhood and Youth. International Applications of the Capability Approach in Schools and Beyond, edited by Caroline Hart, Mario Biggeri, and Bernhard 
Babic, 17-43. London: Bloomsbury Academic.

Jacobs, Janis E. 1991. "Influence of Gender Stereotypes on Parent and Child Mathematics Attitudes." Journal of Educational Psychology 83 (4): 518-527. doi: 10.1037/00220663.83.4.518.

Jacobs, Janis E, and Martha M. Bleeker. 2004. “Girls' and Boys' Developing Interests in Math and Science: Do Parents Matter?" New Directions for Child and Adolescent Development 106: 5-21. doi: 10.1002/cd.113.

Jacobs, Janis E., and Jacquelynne S. Eccles. 1992. "The Impact of Mothers' Gender-Role Stereotypic Beliefs on Mothers' and Children's Ability Perceptions.” Journal of Personality and Social Psychology 63 (6): 932-944. doi: 10.1037/0022-3514.63.6.932.

Kelly, Anthony. 2012. "Sen and the Art of Educational Maintenance: Evidencing a Capability, as Opposed to an Effectiveness, Approach to Schooling." Cambridge Journal of Education 42 (3): 283-296. doi: 10.1080/0305764X.2012.706255.

Kleinjans, Kristin J. 2010. "Family Background and Gender Differences in Educational Expectations.” Economics Letters 107 (2): 125-127. doi: 10.1016/j.econlet.2010.01.002.

Krishnakumar, Jaya. 2007. “Going Beyond Functionings to Capabilities: An Econometric Model to Explain and Estimate Capabilities." Journal of Human Development 8 (1): 39-63. doi: $10.1080 / 14649880601101408$.

Kuklys, Wiebke. 2005. Amartya Sen's Capability Approach, Theoretical Insights and Empirical Applications. Berlin: Springer-Verlag.

Muthén, Bengt. 1979. “A Structural Probit Model with Latent Variables.” Journal of the American Statistical Association 74 (368): 807-811. doi: 10.1080/01621459.1979.10481034.

Nussbaum, Martha. 1997. Cultivating humanity: a classical defence of reform in liberal education. London: Harvard University Press.

Nussbaum, Martha. 2003. "Capabilities as Fundamental Entitlements: Sen and Social Justice." Feminist Economics 9 (2\&3): 33-59. doi: 10.1080/1354570022000077926. 
OECD. 2006. Women in Scientific Careers: Unleashing the Potential. Paris: OECD. doi: 10.1787/9789264025387-en.

OECD. 2007. PISA 2006 - Volume 2:Data. Paris: OECD. doi: 10.1787/9789264040151-en.

OECD. 2009. PISA 2006 Technical Report. Paris: OECD. doi: 10.1787/9789264048096-en.

OECD. 2012. Closing the Gender Gap: Act Now. Paris: OECD. doi: 0.1787/9789264179370-en.

Peraita, Carlos, and Manuel Sánchez. 1998. “The Effect of Family Background on Children’s Level of Schooling Attainment in Spain." Applied Economics 30 (10): 1327-1334. doi: 10.1080/000368498324940.

Sikora, Joanna, and Artur Pokropek. 2012. “Gender Segregation of Adolescent Science Career Plans in 50 Countries." Science Education 96(2): 234-264. doi: 10.1002/sce.20479.

Terzi, Lorella. 2007. "The capability to be educated." Chap. 2 in Amartya Sen's Capability Approach and Social Justice in Education, edited by Melanie Walker, and Elaine Unterhalter, 25-44. Basingtoke: Palgrave Macmillan.

Twenge, Jean M., and W. Keith Campbell. 2001. "Age and Birth Cohort Differences in SelfEsteem: A Cross-Temporal Meta-Analysis.” Personality and Social Psychology Review 5 (4): 735-748. doi: 10.1207/S15327957PSPR0504_3.

Vaughan, Rosie Peppin, and Melanie Walker. 2012. "Capabilities, Values and Education Policy." Journal of Human Development and Capabilities 13 (3): 495-512. doi: 10.1080/19452829.2012.679648.

Walker, Melanie. 2005. “Amartya Sen's Capability Approach and Education.” Educational Action Research 13 (1): 103-110. doi: 10.1080/09650790500200279.

Walker, Melanie and Elanie Unterhalter. 2007. "The Capability Approach and its Potential for Work in Education." Chap. 1 in Amartya Sen's Capability Approach and Social Justice in Education, edited by Melanie Walker, and Elaine Unterhalter, 1-18. Basingtoke: Palgrave Macmillan. 
Yeung, W. Jean, Miriam R. Linver, and Jeanne Brooks-Gunn. 2002. "How Money Matters for Young Children's Development: Parental Investment and Family Processes." Child Development 73 (6): 1861-1879. doi: 10.1111/1467-8624.t01-1-00511.

Zohar, Anat, and David Sela. 2003. "Her Physics, his Physics: Gender Issues in Israeli Advanced Placement Physics Classes.” International Journal of Science Education 25 (2): 245-268. doi: 10.1080/09500690210126766. 